særlig innsikt i moderne kreftforskning. Jeg vil påpeke at det de siste tiårene har vært en revolusjon innen forståelsen av bl.a. epigenetiske mekanismer i kreftutvikling (3), og det er i dag bred enighet om at kreftutvikling innebærer samspill mellom genetiske, epigenetiske og miljøbetingede faktorer. Hvis Mysterud og Poleszynski ønsker å diskutere mitokondrienes rolle i carcinogenese, bør de dessuten velge et annet utgangspunkt enn min kronikk om hvordan allmennheten oppfatter kreftproblematikken.

Når det gjelder nyere studier på sammenhengen mellom kreft og karbohydratstoffskiftet, trekker Mysterud og Poleszynskis igjen konklusjoner som grenser mot det absurde. Det er i dag bred faglig enighet om at kostholdet er viktig både i forebygging og terapi av kreft, og jeg har ennå til gode å møte en ernæringsekspert som er uenig $i$ at vi bør redusere sukkerforbruket $\mathrm{i}$ befolkningen. At det er sammenheng mellom kreftutvikling og høy blodglukose betyr derimot ikke at karbohydrater i kosten er årsaken til all kreft eller at lavkarbodietter er løsningen på kreftproblematikken.

Mysterud og Poleszynskis strategi er å sette sammen fragmenter av forskning for å promotere en ekstrem kostholdsideologi. At god forskning handler om å være kritisk til egne hypoteser, har de åpenbart ikke forstått. De er imidlertid flinke til å utnytte media, og det er et dilemma om man skal kommentere slike innlegg. Jeg har valgt å kommentere, ikke for å gi anerkjennelse til den absurde argumentasjonen, men for å sette fokus på problemene knyttet til kreft og forskningsformidling. Kreft er en av samfunnets største utfordringer, og det er viktig å formidle en realistisk og kunnskapsbasert forståelse av problematikken.

\section{Jarle Breivik}

jbreivik@medisin.uio.no

Jarle Breivik (f. 1968) er professor ved Universitetet i Oslo.

Ingen oppgitte interessekonflikter.

\section{Litteratur}

1. Capasso LL. Antiquity of cancer. Int J Cancer 2005; 113: 2-13.

2. Breivik J. Når Darwin møter Hippokrates. I: Hessen DO, Lie T, Stenseth NC, red. Darwin - Verden ble aldri den samme. Oslo: Gyldendal, 2009: 165-95.

3. Sharma S, Kelly TK, Jones PA. Epigenetics in cancer. Carcinogenesis 2010; 31 27-36.

\section{Re: Legar må bidra i medisinsk grunnutdanning}

Takk for ein fin artikkel om Legeforeningen sitt arbeid med grunnutdanning (1). Eg ser fram til endeleg rapport til hausten. Det er fint å sjå aktiv debatt om undervisningsspørsmåla som du nemner. Eg deltok i mange slike debattar då eg sjølv var student i Bergen kring 1995. Vi hadde eit landsomfattande engasjement i foreininga Norsk Forening for Medisinsk Utdanning, ei spesialforeining i Legeforeningen. Vi hadde fleire møter saman med Legeforeningen om desse spørsmåla, saman med Oxford University. Møterekka heitte «Learning in Medicine» og var leia av Hans Asbjørn Holm, visegeneralsekretær i Legeforeningen. Den europeiske medisinstudentorganisasjonen (EMSA) hadde og fleire møter om dette. Eg forstår EMSA framleis held konferansar om medisinsk utdanning, og er endå meir aktive no enn før.

\section{Karl Anton Undeland}

kaunde@gmail.com

Karl Anton Undeland (f. 1969) er seniorrådgiver i Helsedirektoratet. Ingen oppgitte interessekonflikter.

\footnotetext{
Litteratur

1. Christiansen MH. Legar må bidra i medisinsk grunnutdanning. Tidsskr Nor Legeforen 2015; 135: 1242
}

\section{Re: Lytte, lete, tenke}

I en utmerket lederartikkel i Tidsskriftet nr. 14/2015 skriver Petter Gjersvik blant annet at diagnoser ikke må stilles for tidlig, ved å gjette eller når man er på tynn is (1). En av våre lærere på Ullevål tidlig på 1960-tallet kalte slike diagnoser, vel å merke hvis de var riktige, for «pseudogeniale lyndiagnoser». En genial betegnelse som fortjener å ikke gå i glemmeboken.

\section{Arne C. Jørgensen}

ac.j2@online.no

Arne C. Jørgensen (f. 1939) er lege.

Ingen oppgitte interessekonflikter.

Litteratur

1. Gjersvik P. Lytte, lete, tenke. Tidsskr Nor Legeforen 2015; 135: 1217

\section{Re: Nyttig, men litt kjedelig}

Jeg takker for en positiv anmeldelse av boka «Komorbiditet i somatikk og psykiatri (1). Forståelse, betydning og konsekvenser.», der jeg er medforfatter. Jeg kan ikke se at tittelen på anmeldelsen, «Nyttig, men litt kjedelig», er dekkende for innholdet i anmeldelsen. Sammenhengen mellom premisser og konklusjon er mangelfull, etter min vurdering.

\section{Alv A. Dahl}

alvdah@ous-hf.no

Alv A. Dahl (f. 1944) er forskningsrådgiver ved Oslo universitetssykehus. Oppgitte interessekonflikter: Dahl er en av forfatterne av den anmeldte boka.

Litteratur

1. Lunde L-H. Nyttig, men litt kjedelig. Tidsskr Nor Legeforen 2015; 135: 1277.

\section{Re: Psykisk syke lever kortere}

I Tidsskriftet nr. 3/2015 skriver Lien og medarbeidere at «Den forventede levetid er omkring 20 år kortere for mennesker med alvorlige psykiske lidelser enn for befolkningen for øvrig.» og at «Overdødeligheten er til stede i alle psykiatriske diagnosegrupper. Den er høy innenfor alle somatiske sykdomsgrupper, som hjerte- og karsykdommer, diabetes, kreft og infeksjoner.» (1).

Sundhedsstyrelsen omtalte nylig i «Nyt om bivirkninger» 50 innberetninger om dødsfall for ett enkelt antipsykotika (olanzapin), men siden bivirkninger vanligvis ikke innrapporteres må man anta at det er store mørketall (2). Ifølge en retrospektiv analyse har Parkinson-pasienter som tar antipsykotika dobbelt så stor risiko for å dø i løpet av 180 dager etter behandlingsoppstart sammenlignet med de som ikke fikk legemidlene (3). Den omtalte overdødeligheten skyldes antakelig i stor grad forskrivning av psykofarmaka som gjør mer skade enn nytte (4-7).

Gøtsche et al estimerer at psykofarmaka årlig tar livet av 500000 mennesker over 65 år i USA og EU. Myndighetene ignorerer legemidlenes sikkerhetsmangel, hvor bivirkninger også rammer barn, ungdom og middelaldrende hardt, ikke minst utviklingshemmede med eller uten psykisk lidelse (5). Enkelte pårørende opplever forskrivninger av psykofarmaka som ekstremt belastende, slik det fremgår av en bok nylig omtalt i Tidsskriftet (8). Forfatteren skriver i forordet til nevnte bok bl.a. at «Dere dømte meg til et liv i tortur. Dere dømte meg til å se mitt kjæreste, mitt barn, gå til grunne. Dere bandt meg på hender og føtter, tok fra meg min handlekraft. Dere vil ikke snakke med meg, lar meg ikke få vite hva dere tenker, hva dere gjør. Hvorfor dere behandler sønnen min slik dere gjør.» (9). 